\title{
PENINGKATAN KEMAMPUAN BERPIKIR KRITIS SISWA SMP MELALUI PEMBELAJARAN BERBASIS MASALAH PADA KONSEP RESPIRASI
}

\author{
Soleh Hadiryanto, Dina Thaib ${ }^{1}$ \\ Universitas Terbuka
}

\begin{abstract}
This study is based on students critical thinking low ability in solving contextual problems which are faced by students. Problems-based learning is one of alternative learning model to improve students critical thinking. The aim of the study is to analyze problems-based learning efect toward improvement of students critical thinking. The method that used is experiment. In this study, experiment class use problems-based learning and control class use conventional learning. Instruments that used critical thinking test. Wilcoxon test result shows that there is difference on improvement of critical thinking ability significantly $(\alpha 0,05)$ between class that use problems-based learning with class that use conventional instruction; there is also difference on improvement of students critical thinking significantly between students with high ability and students with low ability; and there is significant interaction between learning model with students ability toward students critical thinking.
\end{abstract}

Keywords: Critical Thinking Skills, Problem-based Learning

\begin{abstract}
Abstrak: Penelitian ini didasarkan pada kemampuan siswa rendah berpikir kritis dalam memecahkan masalah kontekstual which yang dihadapi oleh siswa. Masalah pembelajaran berbasis adalah salah satu model pembelajaran alternatif untuk meningkatkan siswa berpikir kritis. Tujuan dari penelitian ini adalah untuk menganalisis masalah pembelajaran berbasis berpengaruh terhadap peningkatan siswa berpikir kritis. Metode yang digunakan adalah eksperimen itu. Dalam studi ini, kelas eksperimen penggunaan masalah berbasis belajar dan menggunakan kelas kontrol pembelajaran konvensional. Instrumen yang digunakan tes berpikir kritis. Hasil uji Wilcoxon menunjukkan bahwa ada perbedaan pada peningkatan kemampuan berpikir kritis signifikan $(\alpha 0,05)$ antara kelas yang menggunakan masalah pembelajaran berbasis dengan kelas yang menggunakan instruksi konvensional; Juga ada perbedaan pada peningkatan siswa berpikir kritis Secara signifikan, antara siswa dengan kemampuan tinggi dan siswa dengan kemampuan rendah; dan ada interaksi yang signifikan antara siswa model pembelajaran dengan siswa menuju kemampuan berpikir kritis.
\end{abstract}

Kata Kunci: Kemampuan Berpikir Kritis, Pembelajaran Berbasis Masalah

\section{PENDAHULUAN}

Pembelajaran adalah upaya menciptakan kondisi belajar sebaik mungkin supaya siswa mau belajar sehingga tercapainya tujuan pembelajaran (Sardiman, 2005). Melalui pembelajaran siswa akan memperoleh kemampuan baik pengetahuan, keterampilan maupun sikap. Demikian juga dalam pembelajaran biologi diharapkan siswa memperoleh kemampuan-kemampuan tersebut. Salah satu kemampuan yang diharapkan dimiliki siswa ialah kemampuan berpikir kritis. Kemampuan berpikir kritis ini sangat penting dimiliki para siswa dalam pelajaran biologi. Ini dikarenakan berpikir kritis itu adalah kemampuan menganalisis fakta, mencetuskan dan menata gagasan, mempertahankan pendapat, membuat perbandingan, menarik kesimpulan, mengevaluasi argumen dan memecahkan masalah (Chance,1986). Kemampuan-

\footnotetext{
${ }^{1}$ Universitas Terbuka
} 
kemmpuan tersebut sangat diperlu- kan dalam mempelajari materi biologi yang berkaitan dengan makhluk hidup dan lingkungannya.

Untuk membekali kemampuan berpikir kritis siswa dapat dilakukan antara lain melalui penerapan pembelajaran berbasis masalah (problem based learning) dalam proses pembelajaran. Sebagaimana kita ketahui objek biologi adalah meliputi seluruh makhluk hidup, termasuk manusia. Dengan demikian, permasalahan dalam biologi senantiasa berkaitan dengan kehidupan sehari-hari. Untuk menghadapi permasalahan yang dihadapi, siswa perlu dilatih untuk dapat memecahkan permasalahan yang ada dalam kehidupan sehari-hari. Dalam memecahkan masalah tentang kehidupan sehari-hari para siswa perlu menggunakan kemampuan berpikir kritis. Kemampuan ini perlu dilatih dan dibiasakan oleh para siswa. Kenyataan di lapangan menunjukkan bahwa tidak sedikit siswa yang tidak mampu memecahkan permasalahan yang berkaitan dengan kehidupan sehari-hari. Sering kali siswa tidak dapat memecahkan permasalahan yang dihadapi. Hal ini terjadi sebagai dampak negatif dari serentetan kegiatan pembelajaran yang tidak mengkondisikan siswa untuk berlatih dan membiasakan diri menghadapi berbagai permasalahan yang harus dipecahkan. Kiranya inilah yang menunjukkan lemahnya proses pembelajaran di sekolah. Kalau kita perhatikan dalam pembelajaran, siswa tidak terbiasa melibatkan diri untuk memecahkan masalah-masalah kontekstual yang ada. Akibatnya kemampuan berpikir kritis menjadi beku, bahkan menjadi susah untuk dikembangkannya. Ini dikarenakan proses pembelajaran kurang mendorong siswa untuk mengembangkan kemampuan berpikir kritis. Dalam hal ini Sudarman (2007) mengatakan bahwa pembelajaran di sekolah kurang diarahkan untuk mengembangkan dan membangun karakter serta potensi yang dimiliki siswa, termasuk didalamnya kurang bahkan tidak memberi kesempatan kepada siswa untuk membangun pengetahuannya sendiri. Proses pembelajaran masih bersifat konvensional, kurang diarahkan untuk membentuk manusia cerdas yang memiliki kemampuan memecahkan masalah-masalah kehidupan. Liliasari (1996:23) mengatakan bahwa lemahnya proses pembelajaran karena kurang mendorong siswa untuk mengembangkan keterampilan berpikir. Mata pelajaran sains belum dapat mengembangkan keterampilan siswa untuk berpikir kritis dan sistematis. Model pembelajaran yang digunakan belum dapat membantu siswa mempero- leh pemahaman konsep dengan baik dan jarang mendorong siswa menggunakan kemampuan berpikir tingkat tinggi.

Kemampuan berpikir kritis sangat penting dimiliki oleh siswa untuk menghadapi berbagai tantangan, mampu memecahkan permasalahan yang dihadapi, mengambil keputusan yang tepat sehingga dapat menolong dirinya dan orang lain dalam menghadapi tantangan kehidupan di era globalisasi ini. Namun demikian kemampuan berpikir kritis itu tidak begitu saja dapat dimiliki dan ditingkatkan dengan mudah oleh para siswa. Untuk memiliki dan dapat meningkatkan kemampuan berpikir kritis, siswa perlu diberikan latihan-latihan dan pembiasaan dengan dihadapkan kepada masalah -masalah nyata yang harus dipecahkan. Dengan sering dihadapkan pada masalah-masalah kehidupan, siswa dapat terangsang untuk berpikir sehingga kemampuan berpikir kritis siswa meningkat. Menurut Enis (1985:54) kemampuan berpikir kritis meliputi lima kelompok indikator berpikir kritis. Pertama, memberikan penjelasan sederhana (elementary clarification). Kedua, membangun keterampilan dasar (basic support). Ketiga, membuat 
inferensi (infering). Keempat, membuat penjelasan lebih lanjut (advanced clarification). Kelima, mengatur strategi dan taktik (strategi and tactics).

Salah satu alternatif model pembelajaran yang sangat memungkinkan dapat meningkatkan kemampuan berpikir kritis siswa yaitu pembelajaran berbasis masalah. Levin (2001:1) mengatakan bahwa pembelajaran berbasis masalah merupakan metode pengajaran yang mendorong siswa untuk menggunakan kemampuan bepikir kritis memecahkan masalah dan penguasaan konsep pada masalah dan isu nyata. Menurut Lee dan Sonmez (2003:7) pembelajaran berbasis masalah adalah suatu pendekatan pembelajaran yang menantang para siswa untuk mencari solusi-solusi dari permasalahan-permasalahan dunia nyata secara individu atau kelompok, untuk mengembangkan keterampilanketerampilan menjadi pebelajar mandiri dan menekankan penggunaan keterampilan-keterampilan berpikir analitis dan kritis. Dengan demikian guru hendaknya dapat menerapkan pembelajaran berbasis masalah untuk dapat merangsang siswa menggunakan kemampuan berpikir kritisnya.

\section{METODOLOGI PENELITIAN}

Metode yang digunakan dalam penelitian ini ialah metode eksperimen.

Tabel 1. Desain Penelitian

\begin{tabular}{|c|c|c|c|}
\hline Kelompok & $\begin{array}{c}\text { Pengukuran } \\
\text { (Pretes) }\end{array}$ & Perlakuan & $\begin{array}{c}\text { Pengukuran } \\
\text { (Postes) }\end{array}$ \\
\hline Eksperimen & $\mathrm{O}$ & $\mathrm{X}_{1}$ & $\mathrm{O}$ \\
\hline Kontrol & $\mathrm{O}$ & $\mathrm{X}_{2}$ & $\mathrm{O}$ \\
\hline
\end{tabular}

Ruseffendi (2001:45)

Keterangan :

$\mathrm{O}=$ Pretes dan postes dengan soal sama

$\mathrm{X}_{1}=$ Pembelajaran Berbasis Masalah

$\mathrm{X}_{2}=$ Pembelajaran Konvensional

Pemilihan dua kelas untuk kelompok eksperimen dan kelompok kontrol dilakukan secara acak kelas, karena kedua kelompok memiliki

Dalam penelitian ini ada dua kelompok sebagai subjek penelitian, yaitu kelompok eksperimen dan kelompok kontrol. Kelompok eksperimen diberi perlakuan khusus dengan pembelajaran berbasis masalah, sedangkan kelompok kontrol tidak diberi perlakuan khusus, hanya diberi perlakuan seperti biasanya yaitu pembelajaran konvensional yang biasa dilakukan di SMP. Variabel dalam penelitian ini terdiri atas variabel bebas dan variabel terikat. Sebagai variabel bebas yaitu model pembelajaran berbasis masalah dan variabel terikatnya yaitu kemampuan berpikir kritis siswa.

Desain eksperimen yang digunakan dalam penelitian ini berbentuk desain kelompok acak pretes dan postes dengan kelompok kontrol (A Randomized PretestPostest Control Group Design). Dengan desain ini pertama dipilih secara acak kelompok kontrol dan kelompok eksperimen. Kemudian dilakukan pretes terhadap kedua kelompok, setelah itu kedua kelompok diberi perlakuan yang berbeda, dan diakhiri dengan pemberian desain penelitian itu dapat dilihat pada tabel 1. berikut ini:

kemampuan yang relatif sama atau homogen dan tidak ada kelas unggulan. Pembelajaran konvensional dilakukan di 
kelas kontrol, dijadikan sebagai pembanding terhadap pembelajaran berbasis masalah yang dilakukan di kelas eksperimen, sehingga diketahui ada tidaknya perbedaan hasil dari kedua macam perlakuan pembelajaran itu. Perbedaan skor antara pretes dan postes (gain) diasumsikan sebagai efek dari perlakuan. Data tentang penguasaan dengan salah satu karakteristik penelitian eksperimen yang dikemukakan oleh Ruseffendi (2001: 39), yaitu bahwa kesetaraan subjek dalam kelompokkelompok yang berbeda perlu ada, agar bila ada hasil berbeda yang diperoleh kelompok, itu bukan disebabkan karena tidak setaranya kelompok-kelompok itu, tetapi karena adanya perlakuan.

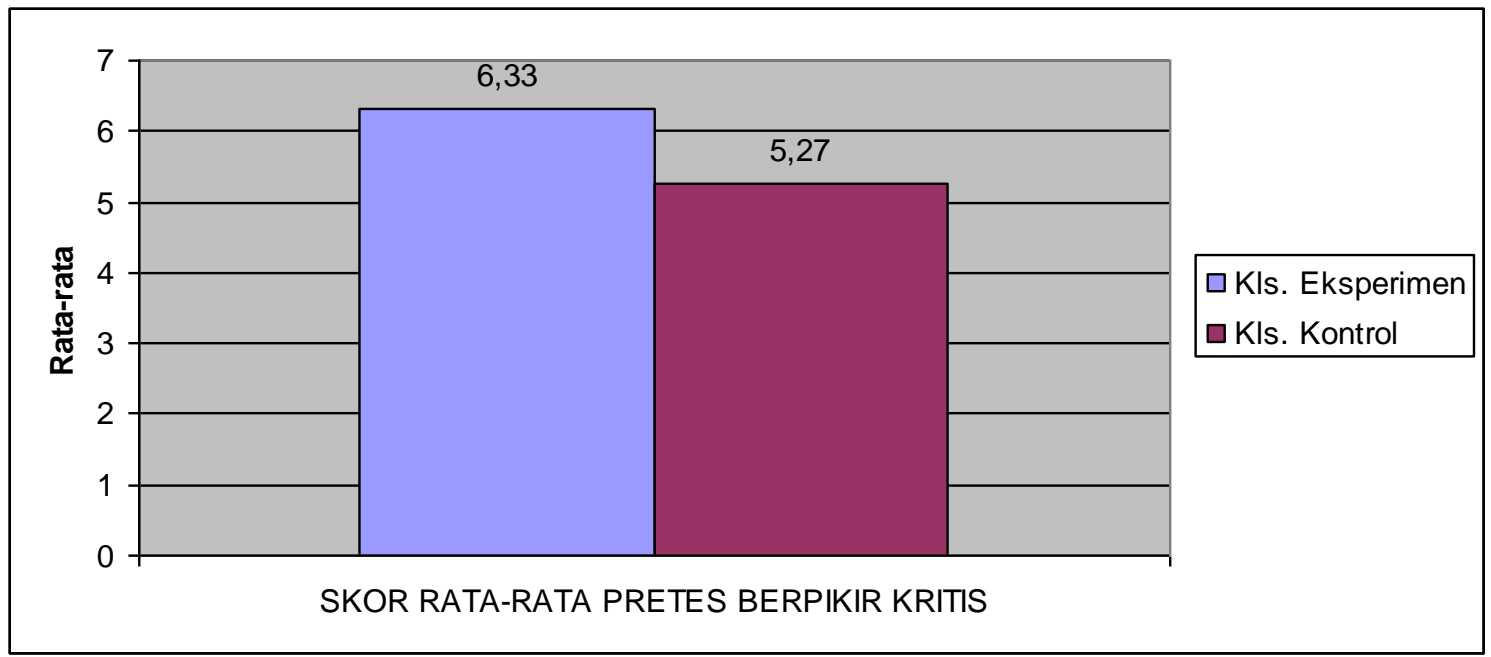

Gambar 1. Rata-rata Pretes Berpikir Kritis Pada Kelompok Eksperimen dan Kontrol

konsep dan berpikir kritis siswa diperoleh pada saat sebelum dan sesudah pembelajaran. Dalam pelaksanaan penelitian, sebelum pembelajaran dimulai kedua kelompok diberikan tes awal (pretes), dan setelah pembelajaran berakhir kedua kelompok di berikan tes akhir (postes). Instrumen yang digunakan dalam penelitian ini yaitu tes kemampuan berpikir iritis. Sedangkan untuk menguji hipotesis penelitian digunakan analisis dengan uji Wilcoxon.

\section{HASIL PENELITIAN DAN PEMBAHASAN}

Dari gambar 1. diperlihatkan bahwa rata-rata pretes berpikir kritis pada kelompok eksperimen dan kontrol relatif sama, rata-rata pretes kelompok eksperimen yaitu 6,33 dan rata-rata pretes kelompok kontrol yaitu 5,27. Ini berarti bahwa kelompok eksperimen dan kelompok kontrol memiliki kemampuan awal yang relatif sama. Hal ini sesuai
Pengetahuan awal yang dimiliki oleh siswa sangat penting untuk diketahui oleh guru, hal ini dimaksudkan agar situasi atau masalah yang disajikan kepada siswa dalam pembelajaran berbasis masalah harus berpadanan (matching) dengan pengetahuan sebelumnya. Guru dapat menjadikan pengetahuan awal yang dimiliki oleh siswa ini sebagai pijakan dalam menyajikan materi pelajaran. Selanjutnya guru bertindak sebagai tangga (scaffolding) atau fasilitator yang dapat membantu siswa untuk mengaitkan antara materi yang diajarkan dengan pengetahuan yang dimiliki sebelumnya. Hal itu sejalan dengan apa yang dikemukakan oleh Ibrahim dan Nur (2000:11) bahwa peran guru pada pembelajaran berbasis masalah kadang melibatkan presentasi dan penjelasan sesuatu hal kepada siswa, namun yang lazim adalah berperan sebagai pembimbing dan fasilitator sehingga 
siswa belajar untuk berpikir dan memecahkan masalah oleh mereka sendiri.

Setelah diberikan perlakuan yang berbeda kepada kelompok eksperimen dan kelompok kontrol, dimana kelompok eksperimen diberikan pembelajaran berbasis masalah dan kelompok kontrol diberikan pembelajaran konvensional, kemudian diberikan postes. Berdasarkan hasil pengujian hipotesis perbedaan ratarata skor postes ( tes akhir) antara kelompok yang memperoleh pembelajaran berbasis masalah

yang diberi perlakuan dengan pembelajaran berbasis masalah memperoleh skor postes yang lebih tinggi dibanding dengan kelompok kontrol yang diberi perlakuan dengan pembelajaran konvensional. Kedua kelompok memang mengalami kenaikan skor postes dari skor pretes, tetapi kenaikan skor postes pada kelompok eksperimen lebih tinggi dibanding dengan kelompok kontrol. Dengan demikian dapat dikatakan bahwa penerapan pembelajaran berbasis masalah pada sistem respirasi dapat meningkatkan berpikir kritis siswa.

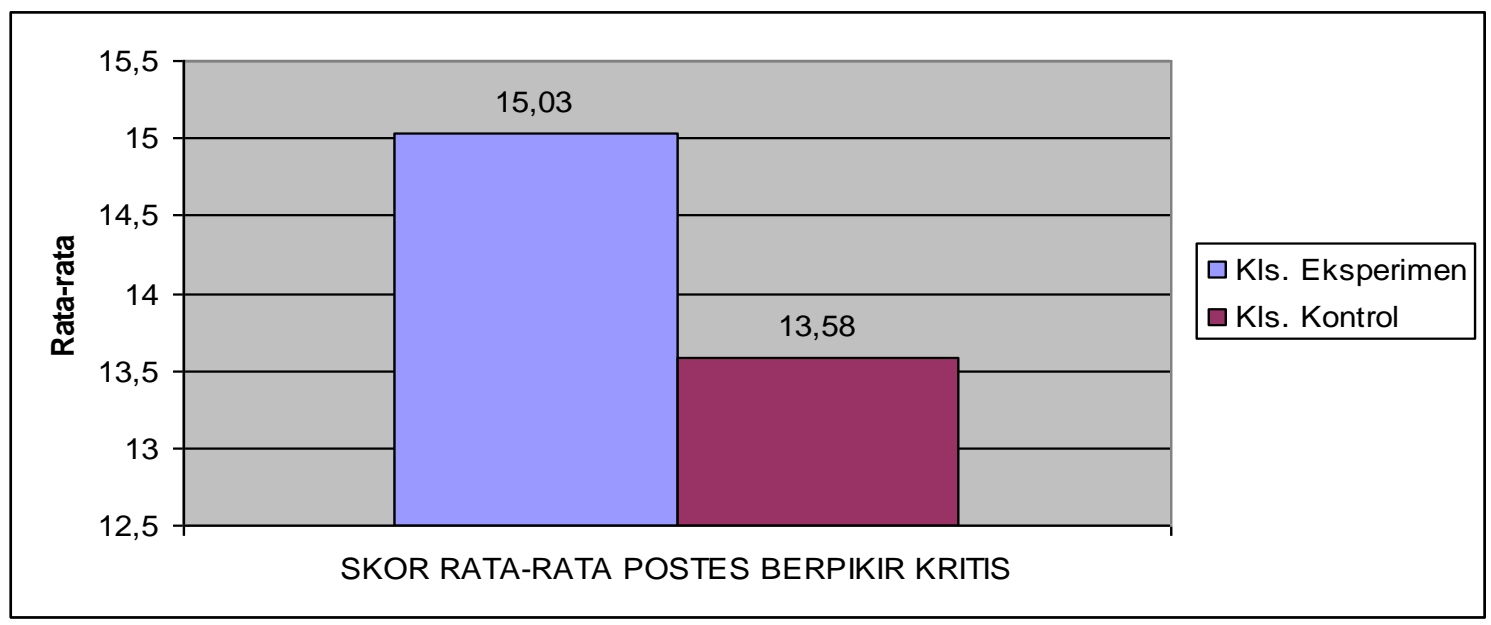

Gambar 2 Rata-rata Postes Penguasaan Konsep dan Berpikir Kritis Pada Kelompok

(kelompok eksperimen) dan kelompok yang memperoleh pembelajaran konvensional (kelompok kontrol), hasil postes pada kedua kelompok untuk aspek berpikir kritis terdapat perbedaan yang berarti pada taraf kepercayaan $95 \%$ ( $\alpha=$ 0,05). Dengan kata lain terdapat perbedaan yang signifikan rata-rata skor postes kemampuan penguasaan konsep dan berpikir kritis antara kelompok eksperimen dengan kelompok kontrol.

Pada gambar 2 diperlihatkan bahwa rata-rata postes berpikir kritis pada kelompok eksperimen dan kontrol tidak sama, rata-rata postes kelompok eksperimen yaitu 15,03 dan rata-rata postes kelompok kontrol yaitu 13,58. Ini berarti bahwa kelompok eksperimen dan kelompok kontrol memiliki kemampuan yang berbeda. Kelompok eksperimen
Setelah dilakukan uji beda rata-rata pretes-postes pada kelompok eksperimen dan kontrol, diperoleh hasil perbedaan yang signifikan skor pretes-postes pada kedua kelompok tersebut. Uji hipotesis dengan menggunakan uji perbedaan dua rata-rata uji Wilcoxon. Setelah postes diberikan kepada kedua kelompok, kemudian skor postes dibandingkan dengan skor pretes. Gambar 3 berikut ini memperlihatkan perbedaan skor pretes 


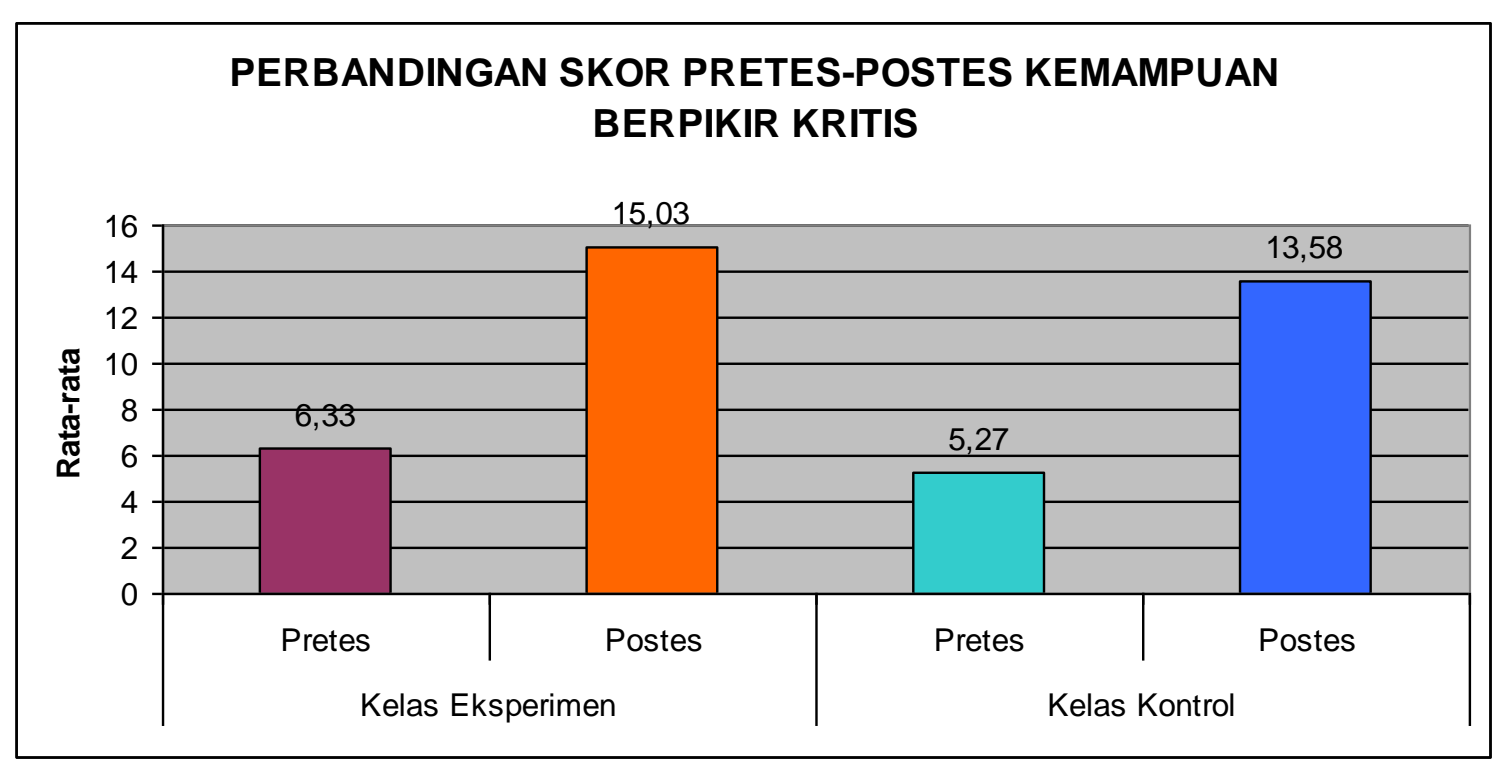

Gambar 3. Perbandingan Skor Pretes dan Postes

dan postes pada kelompok eksperimen dan kelompok kontrol.

Dari gambar 3. terlihat adanya peningkatan berpikir kritis baik pada kelompok eksperimen maupun kontrol. Pada kelompok eksperimen, rata-rata skor pretes berpikir kritis adalah 6,33 dan ratarata skor postes berpikir kritis adalah 15,03. Dari data skor Ini berarti adanya kenaikan skor berpikir kritis pada kelompok eksperimen. Sedangkan pada kelas kontrol rata-rata skor pretes berpikir kritis adalah 5,27 dan rata-rata skor postes berpikir kritis adalah 13,58. Ini berarti adanya kenaikan skor berpikir kritis pada kelompok kontrol. Dengan demikian baik pada kelompok eksperimen maupun kelompok kontrol terjadi peningkatan rata-rata skor berpikir kritis, tetapi peningkatan pada kelompok eksperimen lebih tinggi dibanding dengan kelompok kontrol. Dari hasil uji beda rata-rata pretes - postes aspek berpikir kritis antara kelompok eksperimen dan kontrol diperoleh nilai signifikansi aspek berpikir kritis pada kelompok eksperimen dan kontrol < $\alpha$ (0.05), maka Ho ditolak. Sehingga dapat disimpulkan bahwa terdapat perbedaan yang signifikan skor prestes-postes kemampuan berpikir kritis antara kelompok eksperimen dengan kelompok kontrol. Kedua kelompok mengalami peningkatan kemampuan berpikir kritis, namun peningkatan pada kelompok eksperimen lebih tinggi. Peningkatan ini terjadi setelah kedua kelompok diberi perlakuan yang berbeda, kelompok eksperimen diberikan pembelajaran berbasis masalah sedangkan kelompok kontrol diberikan pembelajaran konvensional. Memperhatikan data skor pretes dan postes tersebut di atas maka dapat disimpulkan bahwa pembelajaran berbasis masalah memberikan pengaruh yang lebih baik dibanding dengan pembelajaran konvensional. Dengan kata lain pembelajaran berbasis masalah dapat meningkatkan kemampuan berpikir kritis siswa.

Untuk mengetahui peningkatan kemampuan befrpikir kritis maka dapat dilakukan dengan menghitung skor $\mathrm{N}$ gain dari skor pretes dan skor postes. Berdasarkan analisis data hasil penelitian, pembelajaran berbasis masalah dapat meningkatkan kemampuan berpikir kritis siswa pada sistem respirasi. Hal ini dapat dilihat dari hasil rata-rata pretest, postes dan N-gain. Untuk lebih jelasnya berikut ini ditampilkan data Skor N-Gain 


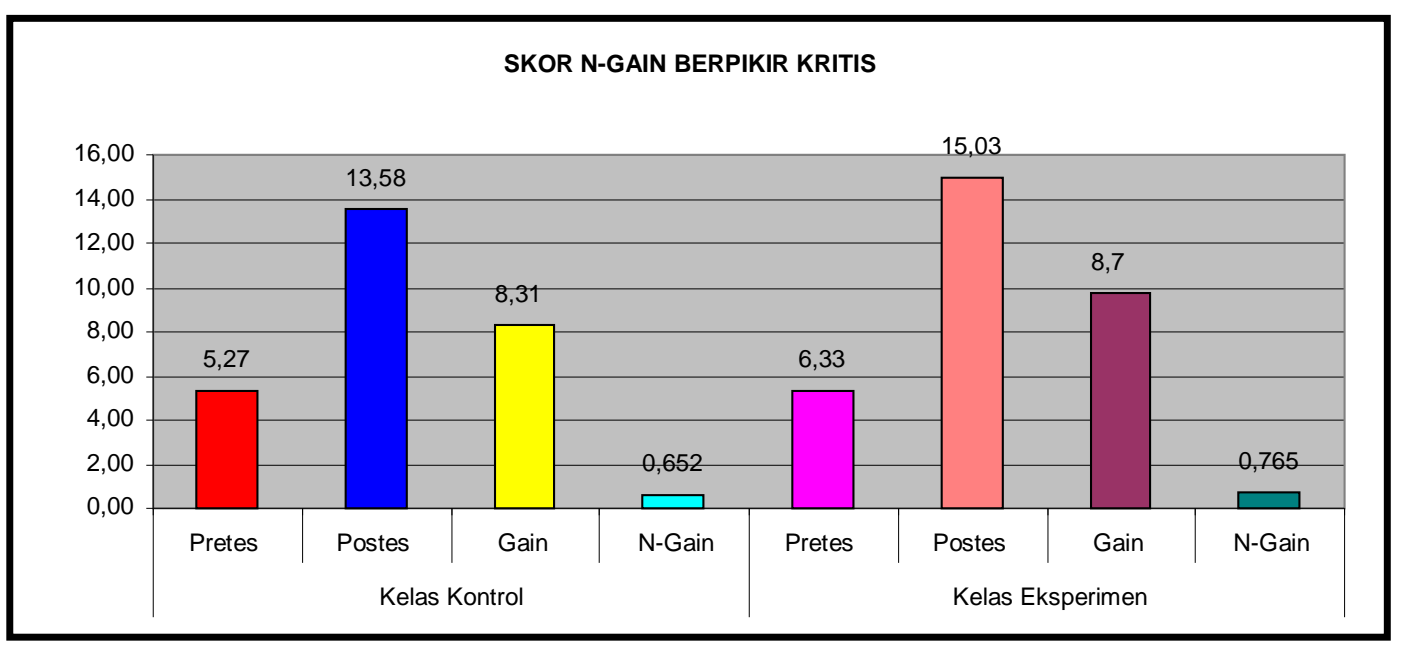

Gambar 4. Skor N-gain Berpikir Kritis

kemampuan berpikir kritis seperti tersaji pada gambar 4. berikut ini.

Dari gambar 4. terlihat pada kelompok eksperimen rata-rata $\mathrm{N}$-gain 0,765 termasuk pada kategori tinggi. Sedangkan pada kelompok kontrol, ratarata $\mathrm{N}$-gain 0,652 termasuk pada kategori sedang. Dari data tersebut dapat disimpulkan bahwa terdapat peningkatan berpikir kritis siswa baik pada kelompok eksperimen maupun kontrol, tetapi peningkatan berpikir kritis pada kelompok eksperimen lebih tinggi dibandingkan dengan peningkatan pada kelompok kontrol. Peningkatan ini terjadi karena dalam pembelajaran berbasis masalah, siswa dihadapkan kepada suatu permasalahan yang harus dipecahkannya. Dengan adanya suatu permasalahan siswa dituntut untuk mencari penyelesaian masalah tersebut. Untuk menyelesaikan masalah siswa melakukan kegiatankegiatan mengidentifikasi masalah, mengeksplorasi permasalahan, dan melakukan penyelidikan ilmiah. Kegiatan-kegiatan yang dilakukan siswa tersebut menuntut siswa untuk berpikir, melihat masalah secara multi dimensi yang semuanya ini dapat melatih kemampuan berpikir siswa. Hal ini sesuai dengan yang dikemukakan oleh Liliasari (2000: 23) menyatakan bahwa pemecahan masalah menggunakan dasar proses berpikir untuk memecahkan kesulitan yang diketahui atau didefinisikan, mengumpulkan fakta tentang kesulitan tersebut dan menentukan informasi tambahan. Selanjutnya Chin \& Chia (2005:64) menyatakan bahwa dalam pembelajaran berbasis masalah (PBL), masalah yang tak terstruktur dalam pembelajaran berbasis masalah dapat meningkatkan proses kognitif siswa yang disertai dengan penalaran yang baik. Untuk memecahkan suatu permasalahan siswa harus mempunyai kemampuan seperti problem solving, berpikir, kerja kelompok, komunikasi, dan kemampuan dalam memperoleh informasi, mengolah informasi dan bertukar informasi.. Kemampuan-kemampuan tersebut dapat dikembangkan melalui implementasi pembelajaran berbasis masalah. Karena pembelajaran berbasis masalah menekankan pada pemecahan masalah yang komplek dalam konteks yang banyak dan mengembangkan kemampuan barpikir tingkat tinggi. Lee \& Sonmez (2003:7) menyatakan bahwa pembelajaran berbasis masalah adalah suatu pendekatan pembelajaran yang menantang para siswa untuk mencari solusi-solusi dari permasalahan permasalahan dunia nyata secara individu atau kelompok, untuk mengembangkan keterampilan-keterampilan menjadi pembelajar mandiri dan menekankan 
pengunaan keterampilan-keterampilan berpikir analitis dan kritis.

Untuk melihat perbedaan peningkatan berpikir kritis antara kelompok eksperimen dengan kelompok kontrol yaitu dengan membandingkan antara N-gain berpikir kritis pada kelompok eksperimen dengan $\mathrm{N}$-gain berpikir kritis pada kelompok kontrol, seperti terlihat pada gambar 5 berikut ini. pembelajaran berbasis masalah guru bertindak sebagai fasilitator, siswalah yang aktif dalam mengkonstruksi pengetahuannya melalui permasalahan yang harus dipecahkannya sehingga siswa didorong untuk berpikir agar dapat memecahkan masalahnya. Hal ini sejalan dengan pendapat Santrock (Desmita, 2006:162) yang mengemukakan untuk mampu berpikir secara kritis siswa harus mengambil peran aktif dalam proses

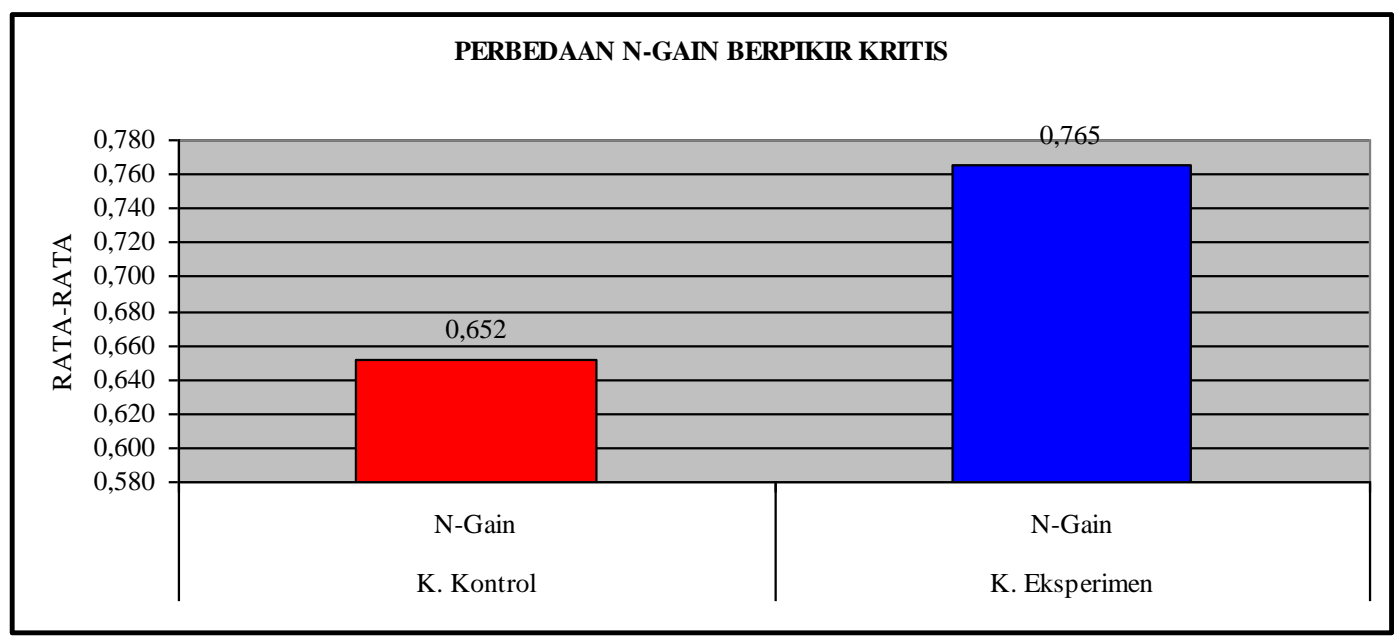

Gambar 5. N-gain Berpikir Kritis Kelompok Eksperimen dan Kelompok Kontrol

Pada gambar 5. terlihat, pada kelompok eksperimen rata-rata $\mathrm{N}$-gain berpikir kritis 0,765 termasuk pada kategori tinggi. Sedangkan pada kelompok kontrol, rata-rata $\mathrm{N}$-gain berpikir kritis 0,652 termasuk pada kategori sedang. Dari data tersebut dapat disimpulkan bahwa terdapat perbedaan Ngain berpikir kritis antara kelompok eksperimen dengan kelompok kontrol. Ngain berpikir kritis kelompok eksperimen lebih tinggi dibanding dengan $\mathrm{N}$-gain berpikir kritis kelompok kontrol. Ini artinya terdapat perbedaan peningkatan berpikir kritis siswa antara kelompok eksperimen dengan kelompok kontrol. Peningkatan berpikir kritis pada kelompok eksperimen lebih tinggi dibanding dengan peningkatan berpikir kritis pada kelompok kontrol.

Peningkatan berpikir kritis dapat terjadi karena dalam implementasi belajar. Berbeda dengan yang diimplementasikan dalam pembelajaran konvensional, dimana siswa pasif karena pembelajaran konvensional berpusat pada guru (teacher centered).

Dalam pembelajaran berbasis masalah siswa harus membuat atau memunculkan pertanyaan-pertanyaan tentang apa yang dibutuhkan untuk diketahui dan apa yang dilakukan untuk mengetahui apa yang belum diketahui. Membuat pertanyaan - pertanyaan dan memutuskan apa yang akan dilakukan untuk menjawab pertanyaan apa yang perlu diketahui merupakan kemampuan berpikir kritis yang terdapat dalam implementasi pembelajaran berbasis masalah. Hal ini sesuai dengan pendapat Jones (Lee \& Sonmez, 2003:24) yang menekankan bahwa memunculkan pertanyaan-pertanyaan yang tepat adalah aspek yang paling kritis dari PBL. 
Dalam pembelajaran berbasis masalah dimungkinkan siswa memecahkan suatu masalah yang mewakili kejadian-kejadian nyata, siswa terlibat dalam perilaku berpikir yang memungkinkan siswa mempunyai kemampuan baru. Kemampuan ini dapat mereka terapkan pada masalah-masalah lain yang mempunyai ciri formal sama. Hal ini sesuai dengan yang dikemukakan oleh Winkel,W.S (2007: 523) yang menyatakan bahwa apabila anak didik mampu mengembangkan konsep, kaidah, prinsip dan cara-cara untuk memecahkan masalah, anak didik tersebut mempunyai bekal yang dapat ditransfer ke bidang lain, di mana konsep kaidah, prinsip dan caracara pemecahan masalah mula-mula diperoleh.

Berdasarkan hasil analisis data tentang tanggapan siswa terhadap pembelajaran berbasis masalah menunjukkan tanggapan yang positif. Persepsi siwa tentang pembelajaran berbasis masalah adalah rata-rata siswa $(3,05)$ berpendapat bahwa model pembelajaran yang diterapkan oleh guru merupakan model pembelajaran yang baru dialaminya. Siswa menyatakan merasa termotivasi dalam pembelajaran. Hal ini dimung- kinkan karena siswa dihadapkan kepada masalah yang menantang mereka untuk memecahkanya. Masalah yang diberikan adalah masalah nyata yang ada dalam kehidupan siswa sehingga siswa termotivasi untuk memecahkannya. Masalah yang harus dipecahkan siswa adalah masalah yang kompleks dan nyata dalam kehidupan, semuanya ini digunakan untuk memotivasi siswa agar siswa mengidentifikasi dan mencari konsep dan prinsip dalam membahas masalah yang telah diberikan. Motivasi siswa dalam pembelajaran berbasis masalah ini dapat dilihat dari aktivitas siswa selama pembelajaran dan karya yang dihasilkan siswa. Setiap kelompok berusaha untuk menanpilkan karya sebaik mungkin.
Siswa juga menyatakan kesukaannya dan berminat dalam pembelajaran berbasis masalah. Hal ini dimungkinkan karena pembelajaran berbasis masalah mengubah peran siswa dari pebelajar yang pasif menjadi pebelajar yang aktif. Dalam pembelajaran berbasis masalah siswa diberikan kesempatan seluas-luasnya untuk menyelesaikan masalahnya. Guru bukan lagi satu-satunya orang sebagai pemberi informasi tetapi siswalah yang aktif membangun pengetahuannya melalui masalah yang dipecahkannya. Melalui pembelajaran berbasis masalah ini siswa mengidentifikasi, mengeksplorasi permasalahannya, melakukan penyelidikan ilmiah dan menampilkan hasil penemuannya kepada orang lain. Aktivitas-aktivitas yang dilakukan siswa ini akan menumbuhkan minat dan kesukaan siswa terhadap pembelajaran. Hal ini sesuai dengan pendapat Piaget (Oakley, 2004:31) yang mengemukakan bahwa anak-anak tidak hanya menyerap pengetahuan saja, tetapi mereka belajar dengan aktif terlibat dalam proses. Selanjutnya Piaget (Oakley, 2004:31) mengemukakan bahwa pembelajaran yang baik memerlukan keikutsertaan, keterlibatan aktif akan membawa kepada pemahaman dan minat yang lebih besar.

\section{KESIMPULAN}

Berdasarkan analisis data dari hasil penelitian dapat ditarik kesimpulan bahwa pembelajaran berbasis masalah dapat meningkatkan kemampuan berpikir kritis siswa SMP pada sistem respirasi.. Peningkatan berpikir kritis pada kelompok yang belajar dengan pembelajaran berbasis masalah lebih tinggi dibanding dengan kelompok yang belajar dengan pembelajaran konvensional. Terjadi peningkatan kemampuan berpikir kritis siswa pada sistem respirasi baik pada kelompok eksperimen yang diberikan pembelajaran berbasis masalah maupun pada kelompok 
kontrol yang diberikan pembelajaran konvensional. Namun peningkatan kemampuan berpikir kritis siswa pada kelompok eksperimen lebih tinggi dibanding dengan kelompok kontrol.

Melalui uji beda rata-rata dengan uji Wilcoxon diperoleh nilai signifikansi 0,000 pada taraf nyata $\alpha(0.05)$, antara kelompok eksperimen dan kelompok kontrol terdapat perbedaan peningkatan berpikir kritis siswa secara signifikan. Peningkatan kemampuan berpikir kritis siswa pada kelompok yang mengikuti pembelajaran berbasis masalah lebih tinggi dibanding dengan kelompok yang mengikuti pembelajaran konvensional.

Tanggapan siswa terhadap penerapan pembelajaran berbasis masalah ialah bahwa pembelajaran berbasis masalah merupakan pembelajaran yang baru dialami. Di samping itu siswa menyatakan termotivasi, senang dan menjadi lebih berminat dalam belajar.

\section{SARAN}

Merujuk dari kesimpulan dan uraian sebelumnya, penulis mengajukan saransaran sebagai berikut:

1. Pembelajaran berbasis masalah merupakan salah satu model pembelajaran yang memungkinkan siswa untuk dapat mengembangkan kemampuan berpikir kritis siswa. Dengan demikian pembelajaran berbasis masalah dapat dijadikan sebagai salah satu alternatif pembelajaran yang dapat digunakan dalam pembelajaran Sains di lapangan. Tetapi sebaiknya pembelajaran berbasis masalah diberikan pada topik-topik yang sesuai, mengingat tidak semua topik pada Sains dapat efektif disampaikan dengan model pembelajaran tersebut.

2. Dalam pengimplementasian pembelajaran berbasis masalah di lapangan guru memerlukan persiapan yang matang terutama dalam mempersiapkan bahan ajar dan LKS.
Selain itu dibutuhkan keaktifan dan kreativitas guru dalam memotivasi siswa agar berani mengemukakan masalah atau bertanya sehingga pembelajaran dapat berjalan sebagaimana mestinya. Hal ini bukanlah pekerjaan mudah, mengingat siswa kelas VIII SMP masih terlihat canggung dalam mengemukakan masalah ataupun bertanya.

3. Mengingat kelemahan siswa dalam mengajukan masalah, guru sebaiknya menciptakan suasana belajar yang lebih banyak memberikan kesempatan kepada siswa untuk dapat mengungkapkan masalah-masalah yang ada di sekitar siswa dalam kehidupan sehari-hari, sehingga siswa menjadi lebih berani mengemukakan masalah dan lebih percaya diri. Untuk itu guru hendaknya perlu mengawali penyajian masalah atau kegiatan dengan bahasa yang mudah dipahami siswa baru kemudian menggunakan bahasa yang umumnya digunakan.

4. Dalam mengimplementasikan pembelajaran berbasis masalah, guru harus mempersiapkan sarana belajar seperti buku teks, bahan ajar dan LKS seoptimal mungkin sehingga kebutuhan siswa akan informasi tercukupi.

5. Untuk materi respirasi, siswa sebaiknya diajak langsung ke lingkungan yang sebenarnya agar siswa dapat langsung mengidentifikasi masalah-masalah yang ada di lingkungan tersebut.

\section{DAFTAR PUSTAKA}

Chin \& Chia, (2004 a). Implementing Project Work in Biology through Problem-based Learning. Journal of Biological Education.38(2),6975. Tersedia [Online] http://www. Iob.org/downloads/277.pdf. [ 14 02- 2007] 
Desmita.

(2006).

Psikologi

Oakley,

L. (2004). Cognitive

Perkembangan. Bandung : PT.

Remaja Rosda Karya

Enis, Robert H. (1985). Goal for a critical

Thinking Curriculum. Dalam A.L

Costa

ed.

Developing Mind : A Resource

Book for Teaching Thinking Alexandria

ASCD 43-45.

Ibrahim, M. (2004). Kumpulan Makalah

Pengenalan

Strategi

Pembelajaran Biologi Di

perguruan Tinggi . Pekanbaru :

Universitas Riau

Levin.B. (2001). Energizing Teacher

Education And Professional

Development With Problem

Based Learning. Alexandria. ASCD.

Liliasari. (1996). Beberapa Pola Berpikir

Dalam

Pembentukan

Pengetahuan

Kimia Oleh Siswa SMA. Disertasi

Pasca Sarjana IKIP Bandung.

Tidak diterbitkan.

Development. New York: Routledge

Ruseffendi, (2001). Dasar-Dasar Penelitian Pendidikan dan Bidang Non-Eksakta

Lainnya. Semarang: IKIP Semarang Press

Sonmez and Lee, H. (2003). ProblemBased Learning in Science. Tersedia [On line] http: www.ericse.org. [01 Mei 2007].

Sardiman. (2007) Interaksi dan Motivasi Belajar Mengajar. Jakarta : PT Raja Grafindo Persada

Sudarman. (2007). Problem Based Learning : Suatu Model Pembelajaran Untuk Mengembangkan dan Meningkatkan Kemampuan Memecahkan Masalah. Jurnal Pendidikan Inovatif Vol 2. No YSN-KPS. Balikpapan.

Winkel, W. S. (1999). Psikologi Pengajaran. Jakarta: PT Grasindo. 